\title{
Overview about GIS multi-criteria spatial analysis for micro hydropower plant site suitability in South Ogan Komering Ulu District, South Sumatera, Indonesia
}

\author{
Wawan Hendriawan Nur $^{1}$, Yuliana ${ }^{2}$, Yuliana Susilowati ${ }^{3}$, Yugo Kumoro ${ }^{4}$, Yunarto ${ }^{5}$ \\ ${ }_{1,3,4,5}$ Research Center for Geotechnology, Indonesian Intitute of Sciences \\ Komplek LIPI Sangkuring Gedung 80, Bandung 40135, West Java, Indonesia. \\ ${ }^{2}$ Regional Development Planning Agency and Research Development of South OKU \\ Pelangki, Muaradua, Kabupaten OKU Selatan, 32211, South Sumatera, Indonesia
}

\section{Article Info \\ Article history: \\ Received Sep 31, 2020 \\ Revised Nov 25, 2020 \\ Accepted Dec 18, 2020}

\section{Keywords:}

Analysis site suitability Multi-criteria spatial analysis Spatial analysis MHPP

\begin{abstract}
Morphology in South OKU District is the potential of an MHPP. This potential has not been fully utilized, although many un-electrified villages in several remote areas. Identification planning for MHPP is the most critical planning task and requires multi-criteria spatial analysis. GIS and multicriteria analysis have played an essential role in analyzing suitable locations for MHPP development and consist of detailed investigations of ongoing sites and suitability for specific planning. This research aims to overview GIS multi-criteria spatial analysis for MHPP site suitability based on electricity demands. The most critical data and criteria to decide the best site suitability are un-electrified villages, rivers, land use, slope, landslide vulnerability, and elevation. All of the data were generated into the raster data format. Quantitative modeling used AHP as a multi-criteria analysis method, and a weighted score is determined by considering the comparison of each criterion. Finally, the criterion layer was calculated by open-source QGIS to create a site suitability map. The field study verified the resulting map, and there is a match between the preferred locations and the field survey. The research results preferred Sungai Are, Sindang Danau, and Kisam Tinggi Sub-district as the best suitability for MHPP development.
\end{abstract}

This is an open access article under the CC BY-SA license.

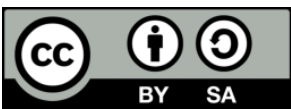

\section{Corresponding Author:}

Wawan Hendriawan Nur

Research Center for Geotechnology

Indonesian Intitute of Sciences

Komplek LIPI Sangkuring Gedung 80, Bandung 40135, Indonesia

Email: wawa018@lipi.co.id

\section{INTRODUCTION}

Hydropower is the largest renewable resource used to meet Indonesia's electricity needs, followed by geothermal, solar, wind, and biomass [1]. Hydropower is hydraulic energy that is extracted by the amount of water falling at the velocity to drive a turbine [2]. The categories of hydropower based on the generating capacity is small hydropower plants (SHP) between 2 and $10 \mathrm{MW}$, mini-hydro power (MHP) between 1 and $2 \mathrm{MW}$, and micro hydropower (MHPP) between 5 and $1000 \mathrm{~kW}$, and pico-hydro (PHPP) to $5 \mathrm{~kW}$ [3].

South OKU District is located in South Sumatera Province, geographically in the Bukit Barisan system with the hilly and mountainous areas. Morphological of hills and mountains, waterfalls, large and steep rivers are suitable locations for MHPP development. This potential has not been fully utilized, even though many un-electrified villages are in several remote areas [4-6]. The terrain of hills and mountains is an 
obstacle for the State Electricity Company (PLN) in distributing electricity for that area [7]. Currently, the limited people in un-electrified villages not supplied by PLN use traditional turbines to meet the electricity needs.

On the other hand, the need for electricity for households, small industries, education, and other activities is high. For example, as one of South Sumatera's largest coffee producers, South OKU District needs electricity to support coffee industries. The coffee industry can increase the economic sector for communities and also increase the regional income. The availability of electricity will significantly raise the economy, standard quality of life, industry, and agriculture [7-11]. Therefore, the potential of hydropower for electricity in South OKU is needed to be explored further.

Morphology in South OKU District is the potential of a micro hydropower plant (MHPP) as an alternative power source. In rural regions, hydropower is one of the best alternatives with low cost and easy maintenance. It is also clean, environment-friendly, and can be used as future energy sources [11-15]. In practice, MHPP development is a tough activity and has many factors to be considered. Identifying a suitable site for MHPP development is one of the most critical planning tasks which requires multi-criteria analysis $[9,16]$. Site suitability is important to understand existing potential locations for MHPP development and determine appropriate activity. The site suitability analysis method consists of a detailed investigation of the land cover and the site's ongoing process [17-20]. Geographical information systems (GIS) and multi-criteria analysis have played an essential role in a site analysis of potential renewable energy resources that consider environmental sustainability [21-28].

Prior studies have used GIS multi-criteria analysis site suitability for hydropower plants and applied GIS to calculate the potency of hydropower from DEM (digital elevation model) data [8, 27, 29-34]. However, the previous studies only concern the potency of hydropower in a region but less considered electricity demands. Therefore, this study aims to overview GIS multi-criteria analysis for MHPP site suitability based on South OKU electricity demands. This study will obtain site suitability for MHPP development map as an initial overview of MHPP development in South OKU. By considering electricity demands, the potency of hydropower in South OKU is expected to be optimally utilized.

\section{RESEARCH METHOD}

\subsection{Study area}

Geographically, the South Ogan Komering Ulu District located $103^{\circ} 22^{\prime}-104^{\circ} 21^{\prime}$ East longitude and $04^{\circ} 14^{\prime}-04^{\circ} 55^{\prime}$ South latitude, has an area of $5493.94 \mathrm{Km}^{2}$ [6]. The topography of South OKU District is mostly highlands of hills and mountains. The altitude ranges from 45 to 1.643 meters above sea level (masl), as shown in Figure 1. Two major rivers flow the Selabung river and the Saka river, which flow into the Komering River. Also, there are 20 rivers and other tributaries scattered throughout the South OKU District.

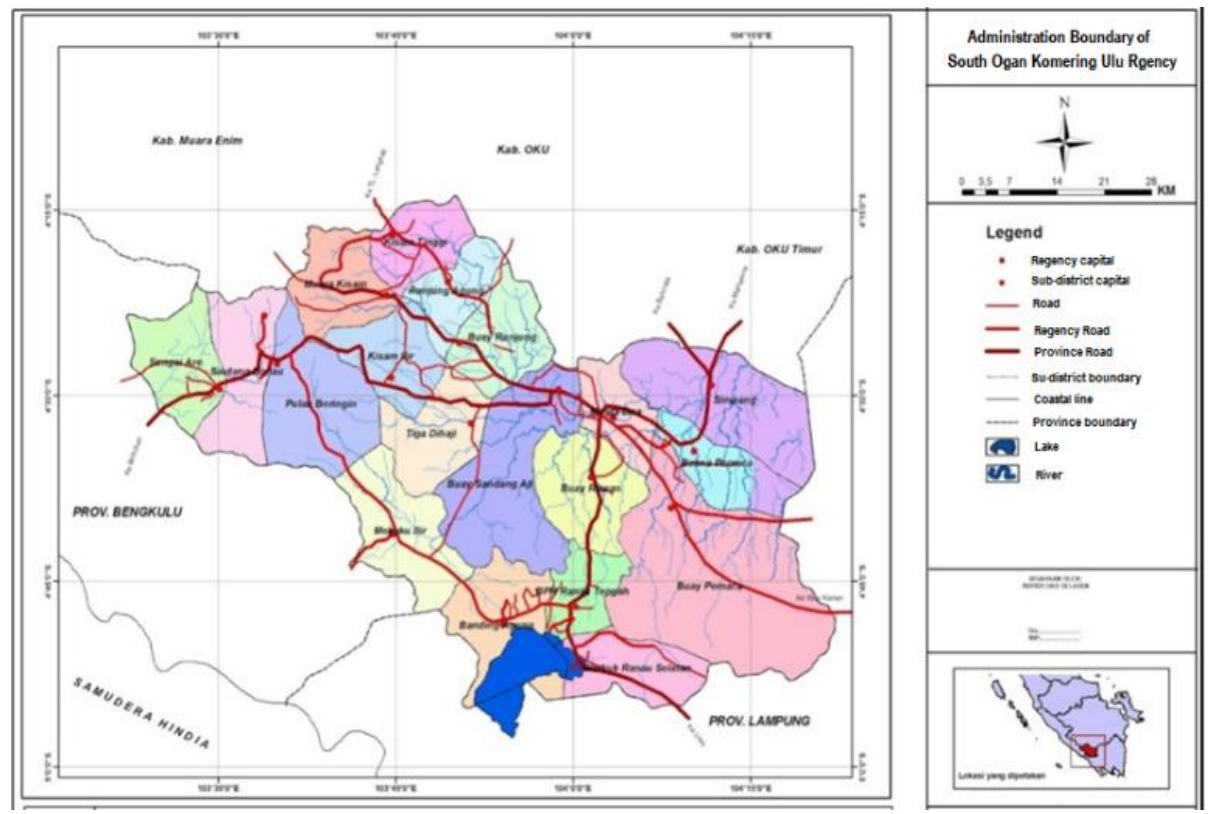

Figure 1. The boundary administration of South OKU District [6] 


\subsection{Research method}

The research method is a literature study, data collection, data processing, relevant attributes selection, classification and weighting attributes using analytical hierarchy process (AHP), weighted attributes calculation using GIS, and field study map verification, see Figure 2. A literature study examines theory and methods in the discussed problems. A literature study was carried out in the site suitability to determine the criteria and attributes that affect MHPP development. Data collection includes un-electrified villages data from Bappeda of South OKU District, river map from Geospatial Information Agency, topographic map from Geospatial Information Agency, SRTM (the shuttle radar topography mission) $30 \mathrm{M}$ from USGS, land use from Geospatial Information Agency, and landslide vulnerability map from Regional Development Planning Agency of South OKU District. Data processing results in thematic maps from the collected data, including un-electrified villages map, main river map, elevation map, slope map, land use map, and landslide vulnerability map. All processed data were converted to raster format because of it is easier and more accurate than the vector format [35].

Relevant attributes were selected based on literature [4, 16, 27, 29-34, 36] and expert knowledge. Relevant attributes consisted of six criteria for site suitability analysis such as un-electrified villages, distance from main river, land use, slope, landslide vulnerability, and elevation. All selected attributes were represented in a map with raster format. Classification and weighting attributes use the analytical hierarchy process (AHP) as a multi-criteria analysis method. AHP was implemented using pairwise comparison to weight each attribute. In pairwise comparison, three stages in pairwise comparison are to create a matrix for each attribute, to set weighting, and to validate weighting for getting consistency ratio (CR) [27, 37-39]. The weighted attributes were added to the raster layer for each criterion, and then calculated using GIS as the most effective tool for analyzing decision support systems' geospatial information.

Moreover, GIS can be used to model and calculate a set of criteria using geodatabase and spatial analysis to produce an output map [40-43]. The spatial analysis applied in QGIS as one of the leading opensource GIS software [42]. The output of this stage is site suitability for MHPP development map. Then, in the final stage, a field survey was carried out to verify the output map.

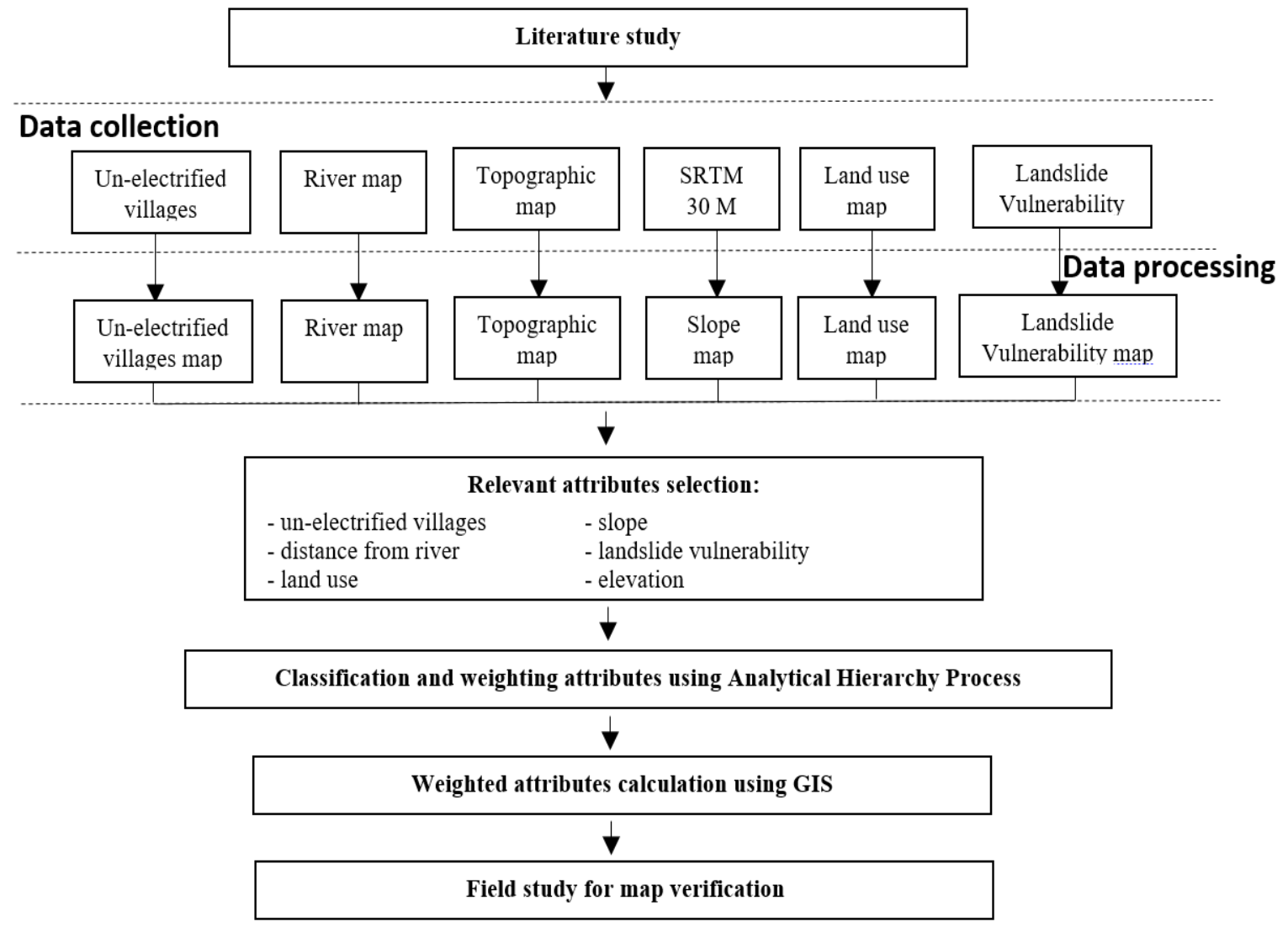

Figure 2. Research method 


\subsection{AHP (analytical hierarchy process) method}

The quantitative spatial analysis used AHP to weight attributes by considering each criterion's comparison. Each criterion is grouped into sub-criteria based on their weight value [44, 45]. Different scores are assigned to each criterion to develop a comparison matrix. These scores represent ratings of preference into appropriate numerical ratios for pairwise comparison. A preference scale between 1 and 9 applied to assess relative preference for any of the two criteria arranged into a matrix [46]. A comparison for each criterion using a numerical scale indicates important or dominant to another criterion. The lowest scale value is one which mean as equal important, and the highest scale value is nine as the extremely importance as shown in Table 1. Weight based on an inverse comparison matrix of the scores for each column based (1):

$$
\mathrm{W}_{\mathrm{i}}=\frac{\mathrm{x}_{\mathrm{i}}}{\Sigma \mathrm{x}_{\mathrm{n}}}
$$

Where,

$W i=$ Weight for each criterion

$X i=$ Sum of scores for each criterion in the inverse matrix

$X n=$ Sum of all scores obtained for each criterion

Table 1. Pairwise comparison weighting scale

\begin{tabular}{lll}
\hline Importance of intensity & Description & Suitability class \\
\hline 1 & Equal importance & Lowest suitability \\
2 & Equal to moderate importance & Very low suitability \\
3 & Moderate importance & Low suitability \\
4 & Moderate to strong importance & Moderate low suitability \\
5 & Strong importance & Moderate suitability \\
6 & Strong to very strong importance & Moderate high suitability \\
7 & Very strong importance & High suitability \\
8 & Strong importance & Very high suitability \\
9 & Extremely importance & Highest suitability \\
\hline
\end{tabular}

\subsection{Classification and weighting criteria and sub-criteria using the AHP}

In this study, six criteria were used in the multi-criteria site suitability analysis, such as unelectrified villages, distance from the main river, land use, slope, landslide vulnerability, and elevation. The pairwise comparison method was used to classify and weight the criteria that contribute to site suitability analysis. A comparison of each criterion based on literature studies and expert knowledge was created in a matrix. Table 2 shows the results of the pairwise comparison value of each criterion weight.

Table 2. Weight the criterion for multi-criteria site suitability

\begin{tabular}{llllllll}
\hline Criteria & \multicolumn{9}{l}{ Pairwise Comparison } & & \multicolumn{2}{c}{ Weight } \\
& I & II & III & IV & V & VI & \\
\hline I & 1.00 & 2.00 & 3.00 & 4.00 & 3.00 & 4.00 & 0.35 \\
II & 0.50 & 1.00 & 2.00 & 3.00 & 3.00 & 4.00 & 0.24 \\
III & 0.33 & 0.50 & 1.00 & 2.00 & 2.00 & 4.00 & 0.16 \\
IV & 0.25 & 0.33 & 0.50 & 1.00 & 2.00 & 3.00 & 0.11 \\
V & 0.33 & 0.33 & 0.50 & 0.50 & 1.00 & 3.00 & 0.09 \\
VI & 0.25 & 0.25 & 0.25 & 0.33 & 0.33 & 1.00 & 0.05 \\
\hline
\end{tabular}

Note: I=Un-electrified villages; II= Distance from main river; III=Land use; $\mathrm{IV}=$ Slope; $\mathrm{V}=$ Landslide vulnerability; $\mathrm{VI}=$ Elevation

The normalized eigenvalues corresponding eigenvectors were calculated to obtain $\mathrm{CR}$ value. This $\mathrm{CR}$ value was used to check weight consistency due to weighted subjectivity in the AHP. The weighting value is valid if the $\mathrm{CR}$ value below 0.1 or $10 \%[38,46]$. The $\mathrm{CR}$ value of this work is approximately 0.04 or $4 \%$, so the weighting value is consistent

Each criterion was classified into three classes called sub-criteria, such as low, medium, high. Each class has its value, which is showing its effect on site suitability analysis. With the same step, the pairwise comparison method was used to classify and weight the sub-criteria that contribute to site suitability analysis. A comparison of each class based on literature studies and expert knowledge was created in a matrix. Table 3 shows the results of the value that associated weights to each sub-criteria. 


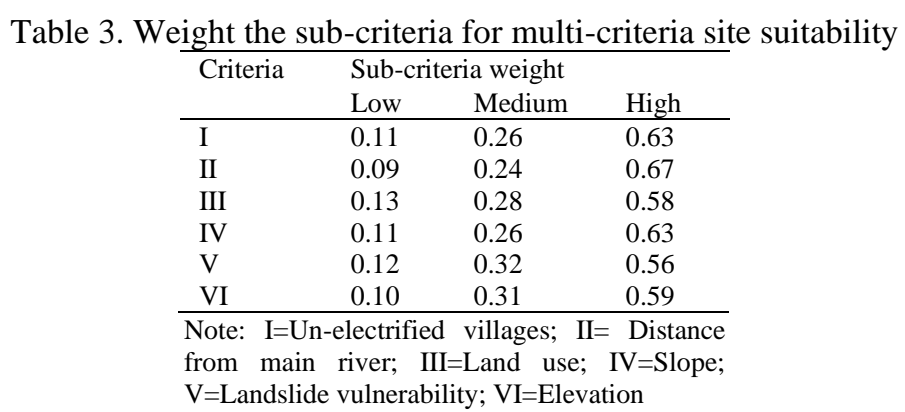

The normalized eigenvalues that correspond to the eigenvectors were calculated to get the $\mathrm{CR}$ value for each sub-criteria. The results of the CR Value for each sub-criterion: (I) 0.033 , (II) 0.006 , (III) $-0,325$, (IV) $0.033,(\mathrm{~V})-0.197,(\mathrm{VI})-0.110$. Because of all CR value is below $10 \%$, the assigned weighting is valid. Furthermore, the criteria and sub-criteria attributes weighted added to the raster layer for further GIS site suitability calculation. QGIS was used to calculate the raster layer and produce a site suitability map for MHPP development.

\section{RESULTS AND DISCUSSION}

\subsection{Un-electrified villages}

Un-electrified villages are essential to represent electricity demand in the South OKU District. In this study, electricity demands are the most important factor in multi-criteria site suitability analysis, which differs from the prior study $[29,30,32]$. The site suitability for MHPP development in OKU Selatan is focused on electricity demands in a specific area. According to data from the Regional Development Planning Agency and Central Bureau of Statistics South OKU, the un-electrified villages in South OKU are shown in Figure 3 [6]. Based on these data, these criteria are divided into three classes, including low indicates that less than two un-electrified villages in Sub-district, medium indicate that two to four unelectrified villages in sub-district and high indicate that more than four un-electrified villages in sub-district. The classes' weight for un-electrified villages is shown in Table 3 and represented in the un-electrified villages map shown in Figure 3.

\subsection{Distance from main river}

A river is a natural flow of water bodies flowing from upstream in the mountains to downstream (estuaries). Streamflow from the river is the main criterion for hydropower [8, 12, 16, 33, 36, 47]. In South OKU, the upper part of the river valley is steep, while in the middle and downstream, the valley is relatively flat and wide. The water flow in the main river of South OKU has good flow, so it is assumed almost in the main river is potential for MHPP development. Almost the rivers in OKU Selatan are possible for hydropower because most of the landscape shows the topography of hills and mountains, which are flowed by many young permanent rivers, flow relatively fast-flowing water a reasonably large stream gradient. The permanent river has the potential for hydroelectric power, where the water discharge will be relatively maintained even though the dry season [7]. The distance from main river criteria divided into three classes, including low indicates more than $1500 \mathrm{M}$ distance from the main river, medium suggests more than $1000 \mathrm{M}$ from the main river, and high mean less than $500 \mathrm{M}$ distance from the main river. These classes have weighted using AHP shown in Table 3 and represented in the distance from the main river map in Figure 4.

\subsection{Land use}

Land use is a land function by human-made, such as forest, plantations, settlement, agriculture, or other human-made. Land use patterns have hydrological implications in the catchment area. Besides, constructing a hydropower plant in each river or stream will directly impact land-use patterns [16, 27, 48]. Land use divided into three classes, such as low: waterbody, lakes, rice field, settlement, and open field; medium: plantation, dryland farming, agriculture, and savanna; high: primary forest, secondary forest, and shrubs. These classes have weighted using AHP, see Table 3, and represented in the weight land use map in Figure 5.

\subsection{Slope}

In the context of multi-criteria analysis for MHPP development, slope needs more attention [16, 27, 29-34, 49]. The topography of South OKU is in the mountain range system, which stretches northwest of the 
southeast, indicated by a very tight contour of height on the topographic map. Volcanic rocks generally form the morphology in the region. The slope in the mountain of South OKU ranges from $45^{\circ}$ to $60^{\circ}$. The directed slopes are formed by volcanic rock; most of the slopes are quite steep. The slope map is made from 30 meters of SRTM data and is classified in to three classes, including low for 0 to $8 \%$, medium for 8 to $25 \%$, and high for more than $25 \%$. Using AHP quantitative method showed weight for slope classes in Table 3 and represented in the weight slope map in Figure 6.

\subsection{Landslide vulnerability}

In the development of MHPP, disaster factors should be strict attention [16]. The reason is that the sustainability MHPP project is closely related to disasters. The landslide vulnerability map shows the level of vulnerability of landslides of a specific area. In areas that have a high vulnerability index, the priority for MHPP development will be lower. These criteria are divided into three classes, including low for low landslide index, medium for medium landslide index, high for high landslide index. The weight for landslide vulnerability classes shown in Table 3 and represented in the weight of the landslide map in Figure 7.

\subsection{Elevation}

The elevation is also taken into account in spatial analysis for the MHPP development. Areas in the highlands are more potential for MHPP development [16, 31, 34]. Elevation containing information on the height in meter, based on this map can be calculated and estimated the magnitude of the slope angle, the gradient of the river, river density, the difference in slope and runway of an area, all of which plays an important role in estimating surface water availability, the amount of speed streamflow in the river. In this work, the elevation map was created from 30 M SRTM data. This elevation has divided into three classes, including low for less than $250 \mathrm{M}$, medium for 250 to $500 \mathrm{M}$, high for more than $500 \mathrm{M}$. Using AHP quantitative method showed weight elevation classes in Table 3 and represented in the weight elevation map in Figure 8.

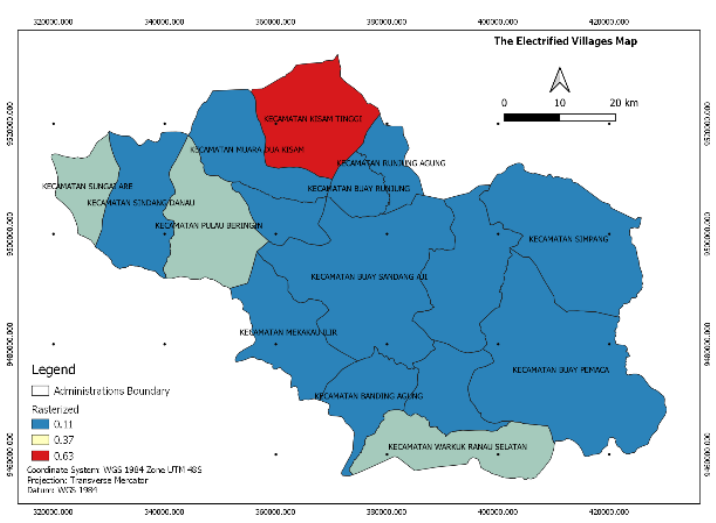

Figure 3. Weight of un-electrified map

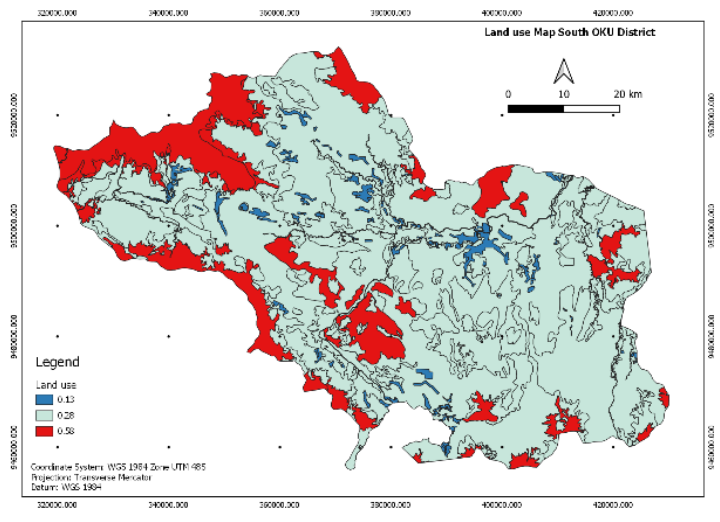

Figure 5. Weight of land use map

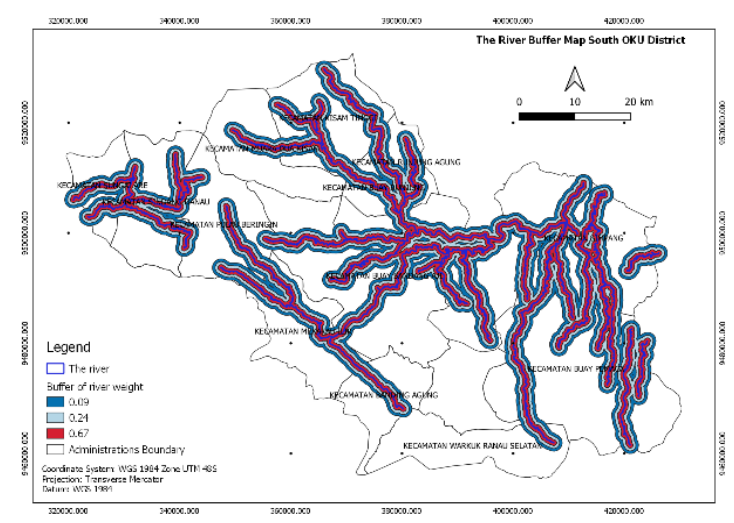

Figure 4. Weight of river distance map

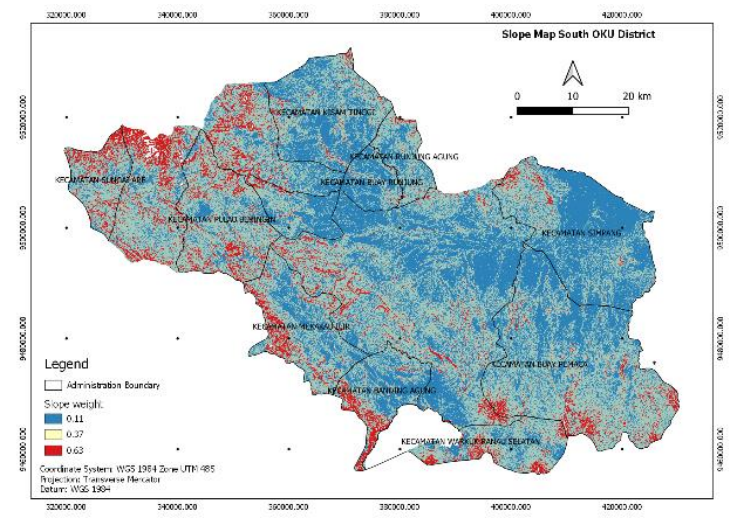

Figure 6. Weight of slope map 


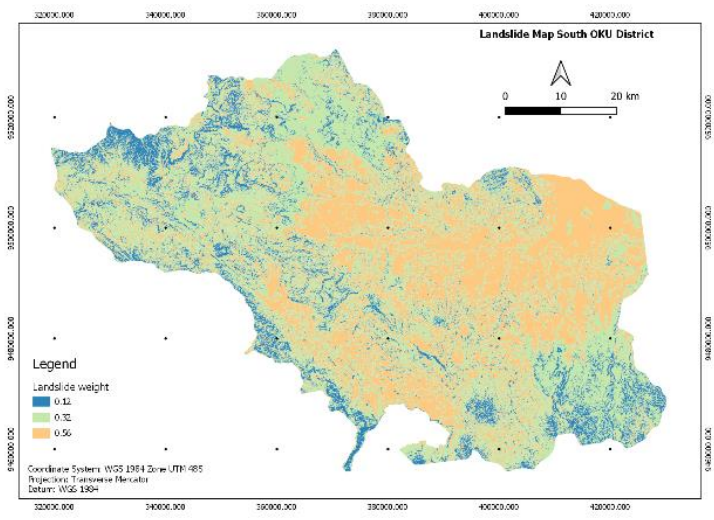

Figure 7. Weight of landslide map

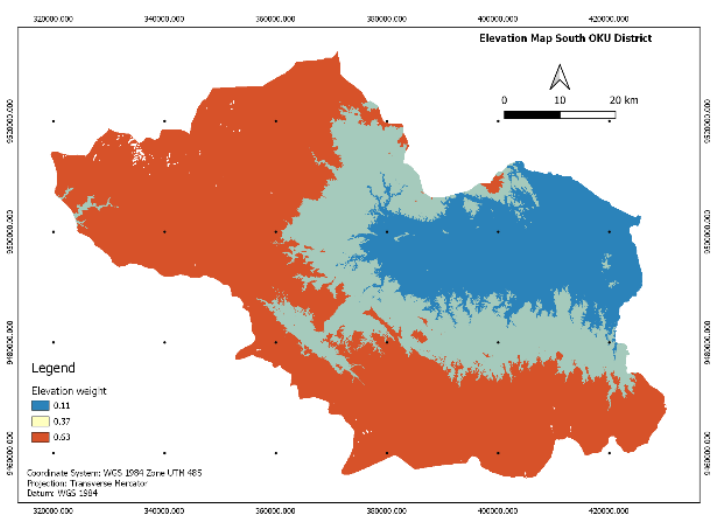

Figure 8. Weight of elevation map

After all the weights are represented in the raster layer, the spatial analysis performed using QGIS. Each criterion and class (sub-criteria) calculated using a raster calculator based on (1). The result is a site suitability map that shows the preferred site for MHP development in the South OKU District as shown in Figure 9. This map is a preliminary study that shows the global overview where the MHPP development needs to be detailed.

The map shows that the best site for the MHPP development in South OKU District is Kisam Tinggi, Muaradua Kisam, Sungai Are, Sindang Danau, Pulau Beringin, Warkuk Ranau Selatan Sub-district. The high index value of this Sub-district because of several characteristics:

- The electricity need is high, because of many un-electrified villages in this sub-district. And in this study, electricity need is an important factor for site suitability MHPP development.

- The high elevation causes upstream rivers are steep and narrow have strong flows and high slopes as the potential for MHPP development.

- The area's topography is a hilly area associated with steep valleys, and fast river flows with high elevation values compared to other sub-districts play an important role in estimating the amount of surface water availability and flow velocity.

- Land use is dominated by closed areas that have green vegetation. This land use is very good for water catchment areas to collect water so that the river flow in the area is maintained for a long period.

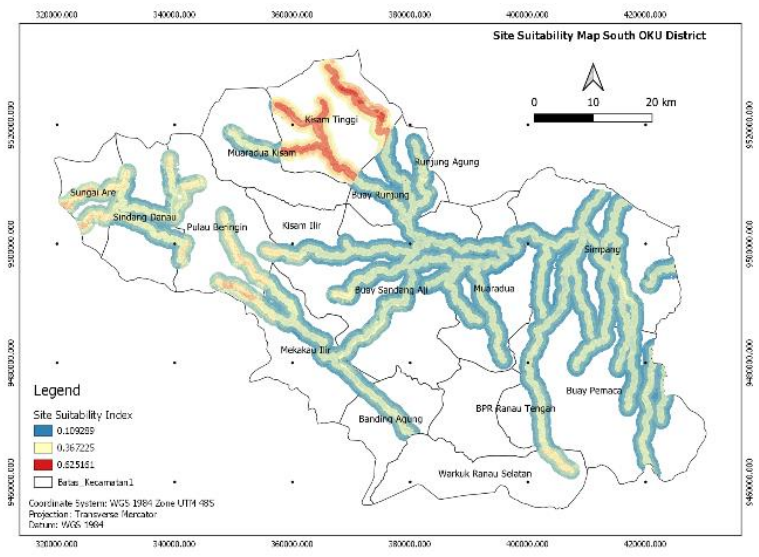

Figure 9. Site suitability map for MHPP development

Prior research on GIS multi-criteria analysis site suitability for hydropower development pays more attention to water resources' potential factors to determine the preferred location for MHPP development [16, 29-33]. Unlike a prior study, this study gives more attention to the electricity demand factor for MHHP development in South OKU. The arguments why the electricity need is the main factor in MHPP development in this study are: 
- Geographically of South OKU in the Bukit Barisan system is hilly and mountainous areas are suitable for MHPP development. Almost all the sub-district areas have hills and mountains, waterfalls, large and steep rivers. These conditions have a consequence; almost sub-district areas have the same potential for MHPP development.

- Almost the rivers in South OKU are possible for hydropower because most of the landscape shows the topography of hills and mountains, which are flowed by many young permanent rivers, flow relatively fast-flowing water a reasonably large stream gradient.

- To get a balance between electricity supply and demand in South OKU. By considering the balance of electricity supply and needs, hydropower's potency in South OKU is expected to be optimally utilized.

\subsection{Field survey}

Furthermore, to verify the site suitability map, a field survey was done to see the suitability of the site suitability map with real conditions in the field. The field survey focused on several sub-districts with a high location suitability index and sub-districts with a low suitability index. The field survey has been done for water flow discharge measurements, head, catchment area, calculation of power capacity, and powerhouse and waterways estimation. During both the rainy and dry seasons, the field survey was done to obtain the minimum and maximum flow discharge.

The results of the field survey, it was found several potential location points for MHPP development in South OKU. The potential of MHPP is spread across several sub-districts in South OKU. The potential location for MHPP development from the field study is Sungai Are, Sindang Danau, Pulau Beringin, Kisam Tinggi, Buay Pemaca, and Banding Agung Sub-district, as shown in Figure 10. And the data for hydropower potential capacity is shown in Table 4. Compared to the output of the GIS multi-criteria analysis map, see Figure 9. There is a correlation between the suggested areas from analysis and the potential for MHHP development according to field studies such as Kisam Tinggi, Sungai Are, and Sindang Danau Sub-district. Verification of site suitability map from GIS and field study confirms this study is convincing, indicated by a match between the preferred locations and the field survey.

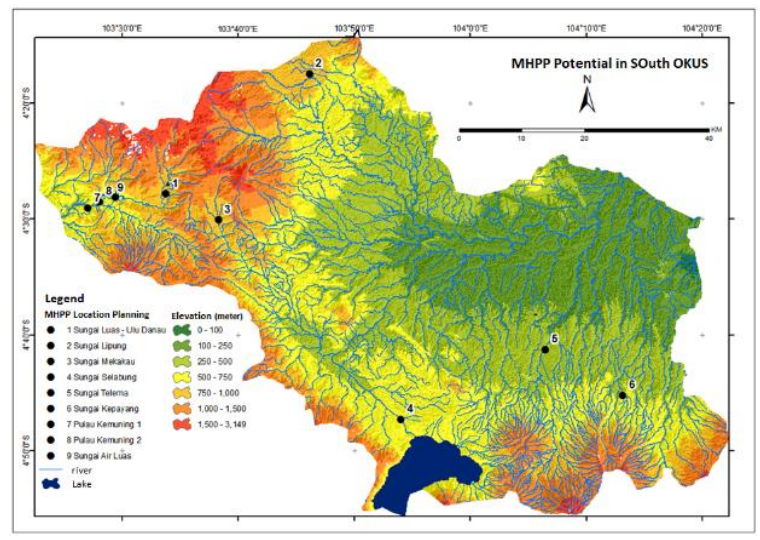

Table 4. Hydropower capacity potential

\begin{tabular}{|c|c|}
\hline No & Potential capacity \\
\hline 1 & $1.4 \mathrm{Mw}$ \\
\hline 2 & $147 \mathrm{Kw}$ \\
\hline 3 & $1.4 \mathrm{Mw}$ \\
\hline 4 & $1.05 \mathrm{Mw}$ \\
\hline 5 & $4.9 \mathrm{Mw}$ \\
\hline 6 & $58.8 \mathrm{Kw}$ \\
\hline 7 & $3.20 \mathrm{Mw}$ \\
\hline 8 & $4.8 \mathrm{Mw}$ \\
\hline 9 & $2.2 \mathrm{Mw}$ \\
\hline
\end{tabular}

flow discharge

Figure 10. MHPP Survey in South OKU

\section{CONCLUSION}

GIS multi-criteria analysis for the MHHP development in South OKU gives more attention to the electricity demands factor as a novelty in the proposed method. In this method, six criteria are used: unelectrified villages, distance from the main river, land use, slope, landslide vulnerability index, and elevation. The GIS calculation results are site suitability map for MHPP development with preferred areas such as Kisam Tinggi, Muaradua Kisam, Sungai Are, Sindang Danau, Pulau Beringin, Warkuk Ranau Selatan Subdistrict. The potential location for MHPP development from filed study are Sungai Are, Sindang Danau, Pulau Beringin, Kisam Tinggi, Buay Pemaca, and Banding Agung Sub-district. Compared to the output map, there is a correlation between the suggested areas for MHHP development and the best potential for MHHP development according to field studies: Kisam Tinggi, Sungai Are, and Sindang Danau Sub-district of site suitability map from GIS and field study confirms this study is convincing, indicated by a match between the preferred locations and the field survey. The results of this proposed method can be a guideline for more detailed MHPP research in South OKU District and help the field surveys be more focused, lower cost, and time-effective. The analysis method in this study is expected can be used in the areas of the same 
characteristics as the South OKU District. For future research, the need to detail for potency variables to result in a more precise map. And a spatial database and a decision support system application are needed to easily manage the potential MHPP development data in South OKU District

\section{CONTRIBUTORS}

All authors have a similar contribution as the main contributor to the article.

\section{ACKNOWLEDGEMENTS}

We are thankful to the Director of Research Center for Geotechnology-Indonesian Institute of Sciences, and Mr. Marfasran Hendrizan for supporting this research.

\section{REFERENCES}

[1] Erinofiardi, P. Gokhale, A. Date, A. Akbarzadeh, P. Bismantolo, A. F. Suryono, A. K. Mainil, and A. Nuramal, "A review on micro hydropower in Indonesia," Energy Procedia, vol. 110, pp. 316-321, 2017, doi: 10.1016/j.egypro.2017.03.146.

[2] C. S. Kaunda, C. Z. Kimambo, and T. K. Nielsen, "Hydropower in the context of sustainable energy supply: A review of technologies and challenges," International Scholarly Research Notices, vol. 2012, pp. 1-15, 2012, doi: $10.5402 / 2012 / 730631$.

[3] A. M. A. Haidar, M. F. M. Senan, A. Noman, and T. Radman, "Utilization of pico hydro generation in domestic and commercial loads," Renewable and Sustainable Energy Reviews, vol. 16, no. 1, pp. 518-524, 2012.

[4] D. P. D Suparyawan, I. N. S Kumara, and W. G. Ariastina, "Study of micro hydropower plant planning in Sambangan Village, Buleleng Regency, Bali," in Bahasa "Studi perencanaan pembangkit listrik mikrohidro di Desa Sambangan Kabupaten Buleleng Bali," Majalah Ilmiah Teknologi Elektro, vol. 12, no. 2, 2013, doi: 10.24843/10.24843/MITE.

[5] D. Arinaldo and J. Christian, "Indonesia's clean energy status report," Institute for Essential Services Reform, 2018.

[6] Central Bureau of Statistics, "South OKU District in numbers," [Online]. Available at: https://okutimurkab.bps.go.id/publication.html, Accessed June 2020.

[7] R. Thayib, S. Nalendra, and E. D. Mayasari, "Estimation of micro hydropower plant resources (MHPP) to meet the electricity needs of Timun Island Village, Lahat District, South Sumatra Province," in Bahasa "Estimasi sumberdaya pembangkit listrik tenaga mikrohidro (PLTMH) dalam pemenuhan kebutuhan listrik Dusun Pulau Timun, Kabupaten Lahat, Provinsi Sumatera Selatan," Jurnal Geomine, vol. 5, no. 3, 2017, doi: 10.33536/jg.v5i3.145.

[8] D. G. Larentis, W. Collischonn, F. Olivera, and C. E. M. Tucci, "Gis-based procedures for hydropower potential spotting," Energy, vol. 35, no. 10, pp. 4237-4243, 2010, doi: 10.1016/j.energy.2010.07.014.

[9] A. I. Chatzimouratidis and P. A. Pilavachi, "multicriteria evaluation of power plants impact on the living standard using the analytic hierarchy process," Energy Policy, vol. 36, no. 3, pp. 1074-1089, 2008, doi: 10.1016/j.enpol.2007.11.028.

[10] A. Alkaisi, R. Mossad, and A. Sharifian-Barforoush, "A review of the water desalination systems integrated with renewable energy," Energy Procedia, vol. 110, pp. 268-274, 2017, doi: 10.1016/j.egypro.2017.03.138.

[11] P. A. Owusu and S. Asumadu-Sarkodie, "A review of renewable energy sources, sustainability issues and climate change mitigation," Cogent Engineering, vol. 3, no. 1, 2016, doi: 10.1080/23311916.2016.1167990.

[12] M. Kamran, R. Asghar, M. Mudassar, and M. I. Abid, "Designing and economic aspects of run-of-canal based micro-hydro system on Balloki-Sulaimanki Link Canal-I for Remote Villages In Punjab, Pakistan," Renewable Energy, vol. 141, pp. 76-87, 2019, doi: 10.1016/j.renene.2019.03.126.

[13] Ministry of Energy and Mineral Resources, "Best practice guide: off-grid micro hydro power plant scheme for rural electricity," Jakarta, MHPP/GIZ, 2011.

[14] D. Gielen, F. Boshell, D. Saygin, M. D. Bazilian, N. Wagner, and R. Gorini, "The role of renewable energy in the global energy transformation," Energy Strategy Reviews, vol. 24, pp. 38-50, 2019, doi: 10.1016/j.esr.2019.01.006.

[15] M. J. Burke and J. C. Stephens, "Political power and renewable energy futures: A critical review," Energy Research \& Social Science, vol. 35, pp. 78-93, 2018, doi: 10.1016/j.erss.2017.10.018.

[16] T. V. Ramachandra, R. K. Jha, S. V. Krishna, and B. V. Shruthi, "Spatial decision support system for assessing micro, mini and small hydel potential," Journal of Applied Sciences, vol. 4, no. 4, pp. 596-604, 2004, doi: 10.3923/jas.2004.596.604.

[17] S. Mukhopadhaya, "GIS-based site suitability analysis : Case study for professional college in Dehradun," J. of Civil Eng. and Envi. Technology, vol. 3, no. 1, pp. 60-64, 2016, doi: p-ISSN: 2349-8404; e-ISSN: 2349-879X.

[18] M. Sarath, S. Saran, and K. V. Ramana, "Site suitability analysis for industries using GIS and multi criteria decision making," ISPRS Annals of Photogrammetry, Remote Sensing \& Spatial Information Sciences, vol. 4, no. 5, pp. 447-454, 2018, doi: 10.5194/isprs-annals-IV-5-447-2018.

[19] J. Malczewski, "GIS-based land-use suitability analysis: A critical overview," Progress in Planning, vol. 62, no. 1, pp. 3-65, 2004, doi: 10.1016/j.progress.2003.09.002.

[20] A. AL-Taani, Y. Al-husban, and I. Farhan, "Land suitability evaluation for agricultural use using GIS and remote 
sensing techniques: The case study of Ma'an Governorate, Jordan,” The Egyptian Journal of Remote Sensing and Space Science, 2020, doi: 10.1016/j.ejrs.2020.01.001.

[21] J. A. J. Capilla, J. A. Carrión, and E. Alameda-Hernandez, "Optimal site selection for upper reservoirs in pumpback systems, using geographical information systems and multicriteria analysis," Renewable Energy, vol. 86, pp. 429-440, 2016, doi: 10.1016/j.renene.2015.08.035.

[22] M. Tahri, M. Hakdaoui, and M. Maanan, "The evaluation of solar farm locations applying geographic information system and multi-criteria decision-making methods: Case study in Southern Morocco," Renewable and Sustainable Energy Reviews, vol. 51, pp. 1354-1362, 2015, doi: 10.1016/j.rser.2015.07.054.

[23] J. M. Sánchez-Lozano, J. Teruel-Solano, P. L. Soto-Elvira, and M. Socorro García-Cascales, "Geographical information systems (GIS) and multi-criteria decision making (MCDM) methods for the evaluation of solar farms locations: Case study in South-Eastern Spain," Renewable and Sustainable Energy Reviews, vol. 24, pp. 544-556, 2013, doi: 10.1016/j.rser.2013.03.019.

[24] Z. Defne, K. A. Haas, and H. M. Fritz, "GIS based multi-criteria assessment of tidal stream power potential: A case study for Georgia, USA,” Renewable and Sustainable Energy Reviews, vol. 15, no. 5, pp. 2310-2321, 2011, doi: 10.1016/j.rser.2011.02.005

[25] R. A. McManamay, N. Samu, S. C. Kao, M. S. Bevelhimer, and S. C. Hetrick, "A multi-scale spatial approach to address environmental effects of small hydropower development," Environmental Management, vol. 55, no. 1, pp. 217-243, 2014, doi: 10.1007/s00267-014-0371-2.

[26] S. Kumar and R. Kumar, "Site suitability analysis for urban development of a hill town ysing GIS based multicriteria evaluation technique: A case study of Nahan Town, Himachal Pradesh, India," International Journal of Advanced Remote Sensing and GIS, vol. 3, no. 1, pp. 516-524, 2014.

[27] J. P. Romanelli, L. G. M. Silva, A. Horta, and R. A. Picoli, "Site selection for hydropower development: A GISbased framework to improve planning in Brazil," Journal of Environmental Engineering, vol. 144, no. 7, 2018, doi: 10.1061/(ASCE)EE.1943-7870.0001381.

[28] P. Punys, A. Dumbrauskas, A. Kvaraciejus, and G. Vyciene, "Tools for small hydropower plant resource planning and development: A review of technology and applications," Energies, vol. 4, no. 9, pp. 1258-1277, 2011, doi: 10.3390/en4091258.

[29] D. A. Pranendya Baskoro, "Mapping the potential of micro hydropower plants in Java Island using geographical information systems," in Bahasa "Pemetaan potensi pembangkit listrik tenaga mikrohidro di Pulau Jawa menggunakan sistem informasi geografis," Thesis, Department of Agricultural and Bio-system Engineering, Bogor Institute of Technology, 2015.

[30] A. L. Aziz, "Web-based geographical information system for mapping the potential of micro hydropower plants in Bogor District," in Bahasa "Sistem informasi geografis berbasis web untuk pemetaan potensi pembangkit listrik tenaga mikrohidro di Kabupaten Bogor," Thesis, Department of Agricultural and Bio-system Engineering, Bogor Institute of Technology, 2016.

[31] Y. Tian, F. Zhang, Z. Yuan, Z. Che, and N. Zafetti, "Assessment power generation potential of Small Hydropower Plants Using GIS Software,” Energy Reports, vol. 6, pp. 1393-1404, 2020, doi: 10.1016/j.egyr.2020.05.023.

[32] S. Vidhya and L. G. R. Sarvani, "Selection of suitable sites for small hydropower plants using geo-spatial technology," International Journal of Pure and Applied Mathematics, vol. 119, no. 17, pp. 217-240, 2018.

[33] P. Rojanamon, T. Chaisomphob, and T. Bureekul, "Application of geographical information system to site selection of small run-of-river hydropower project by considering engineering/economic/environmental criteria and social impact," Renew. and Sust. Energy Reviews, vol. 13, no. 9, pp. 2336-2348, 2009, doi: 10.1016/j.rser.2009.07.003.

[34] S. Izeiroski, B. Idrizi, M. Lutovska, and I. Kabashi, "Gis-based multi criteria analysis of site suitability for exploatation of renewable energy resources," Proc., 7th Int. Conf. on Cartography and GIS, pp. 653-665, 2018.

[35] K. T. Chang, "In introduction to geographic information system: Raster data analysis," Tata McGraw Hill, New Delhi, 2010.

[36] S. Vincenzo, L. Lorena, and F. Gabriele, "Identification of potential locations for run-of-river hydropower plants using a GIS-based procedure," Energies, vol 12, no. 18, pp. 1-20, 2019, 10.3390/en12183446.

[37] J. Malczewski, "On the use of weighted linear combination method in GIS: Commonand best practice approaches," Transactions in GIS, vol. 4, no. 1, pp. 5-22, 2000, doi: 10.1111/1467-9671.00035.

[38] S. Boroushaki and J. Malczewski, "Implementing an extension of the analytical hierarchy process using ordered weighted averaging operators with fuzzy quantifiers in ArcGIS," Computers \& Geosciences, vol. 34, no. 4, pp. 399410, 2008, doi: 10.1016/j.cageo.2007.04.003.

[39] I. Basak and T. Saaty, "Group decision making using the analytic hierarchy process," Mathematical and Computer Modelling, vol. 17, no. 4-5, pp. 101-109, 1993, doi: 10.1016/0895-7177(93)90179-3.

[40] J. Domínguez and J. Amador, "geographical information systems applied in the field of renewable energy sources," Computers \& Industrial Engineering, vol. 52, no. 3, pp. 322-326, 2007, doi: 10.1016/j.cie.2006.12.008.

[41] K. Bunruamkaew and Y. Murayama, "Site suitability evaluation for ecotourism using GIS \& AHP: A case study of surat Thani Province, Thailand," Procedia-Social and Behavioral Sciences, vol. 21, pp. 269-278, 2011, doi: 10.1016/j.sbspro.2011.07.024.

[42] S. Khan and K. Mohiuddin, "Evaluating the parameters of ArcGIS and QGIS for GIS applications," International Journal of Advance Research in Science and Engineering, vol. 7, no. 3, pp. 582-594, 2018.

[43] S. Khan, K. Mohiuddin, and F. Maqbool, "Analysis of paradigm shift in cloud-based GIS systems," International Journal of Advance Research in Science and Engineering, vol. 6, no. 3, pp.2018.

[44] M. Dedeoğlu and O. Dengiz, "Generating of land suitability index for wheat with hybrid system aproach using AHP and GIS," Computers and Electronics in Agriculture, vol. 167, 2019, doi: 10.1016/j.compag.2019.105062. 
[45] D. Mulyadi and W. H. Nur, "Application of analytic hierarchy process for earthquake hazards in the Tanjung Lesung-Panimbang area, Pandeglang," in Bahasa "Aplikasi analitik hirarki proses untuk ancaman bahaya gempa di daerah Tanjung Lesung-Panimbang, Pandeglang," Jurnal RISET Geologi dan Pertambangan Indonesia Journal of Geology and Mining, vol. 28, no. 1, pp. 37-48, 2018, doi: 10.14203/risetgeotam2018.v28.387.

[46] T. L. Saaty, "Decision making with the analytic hierarchy process," International Journal of Services Sciences, vol. 1, no. 1, pp. 83-98, 2008.

[47] K. E. Okedu, R. Uhunmwangho, and M. Odje, "Harnessing the potential of small hydro power in Cross River State Of Southern Nigeria," Sustainable Energy Tech. and Assessments, vol. 37, 2020, doi: 10.1016/j.seta.2019.100617.

[48] E. Hidayah, Indarto, and S. Wahyuni, "Proposed method to determine the potential location of hydropower plant: application at Rawatamtu Watershed, East Java," Procedia Engineering, vol. 171, pp. 1495-1504, 2017, doi: 10.1016/j.proeng.2017.01.480.

[49] E. Gómez-Llanos, P. Durán-Barroso, J. Arias-Trujillo, J. M. Ceballos-Martínez, J. A. Torrecilla-Pinero, and M. Candel-Pérez, "Small and micro-hydropower plants location by using geographic information system," Multidisciplinary Digital Publishing Institute Proceedings, vol. 2, no. 20, 2018, doi: 10.3390/proceedings2201300.

\section{BIOGRAPHIES OF AUTHORS}

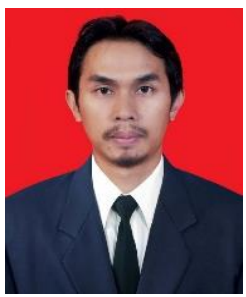

Wawan Hendriawan Nur, is working as a researcher in the Research Center for Geotechnology at Indonesian Institute of Sciences, Indonesia. Completed his Masters in Engineering from the School of Electrical and Informatics Engineering, Bandung Institute of Technology, Indonesia. His research areas include spatial information systems, geographical information systems, and spatial databases.

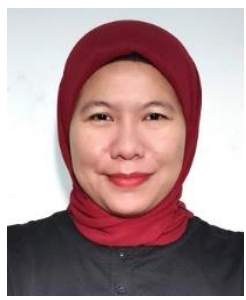

Yuliana, is working at the Regional Development Planning Agency and Research Development of South OKU, Indonesia as the head of research and development. She completed a Bachelor's degree in urban and regional planning from Diponegoro University, Semarang. Her research areas include urban and territorial planning.

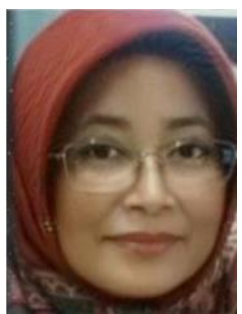

Yuliana Susilowati, is working as a Researcher in the Research Center for Geotechnology at Indonesian Institute of Sciences, Indonesia. She completed her Ph.D. in 2005 in the field of Computer Engineering from Electrical Engineering Department of Institute of Technology Bandung, Indonesia. Her research areas include Digital Image Processing, Remote Sensing, GIS and Environmental Modeling.

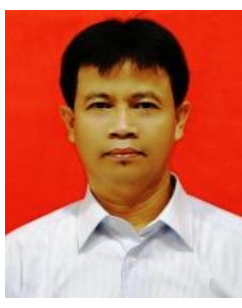

Ir. Yugo Kumoro, is working as a senior researcher in the Research Center for Geotechnology at Indonesian Institute of Sciences, Indonesia. He completed his Bachelor degree for Geological Engineering, Faculty of Mineral Technology, UPN "Veteran" Yogyakarta, Indonesia. His research areas include geology, geological engineering, and natural hazard.

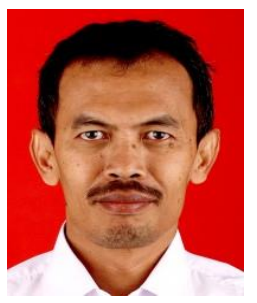

Yunarto, M.T., is working as a senior researcher in the Research Center for Geotechnology at Indonesian Institute of Sciences, Indonesia. He completed his Masters in Engineering from the Padjadjaran University, Bandung, Indonesia. His research areas include geology, natural hazard, vulnerability hazard, and socio-economical hazard. 